\title{
Beata Stelmach-Fita
}

Uniwersytet Pedagogiczny w Krakowie, Polska

Pedagogical University of Cracow, Poland

\section{MONIKA PĘKALSKa}

Uniwersytet Warszawski, Polska

University of Warsaw, Poland

\section{PAWEŁ BARTOSZCZUK}

Szkoła Główna Handlowa, Warszawa, Polska

Warsaw School of Economics, Poland

\section{Usługi informacyine w zakresie nowego zintegrowanego planowania jako czynnik determinujący rozwój przedsiębiorstw}

\section{Information Services in New Integrated Planning as a Factor Determining the Development of Enterprises}

\begin{abstract}
Streszczenie: Artykuł omawia potrzebę monitorowania oraz udostępniania informacji o zjawiskach społeczno-gospodarczych i przestrzennych w Polsce na poziomie regionalnym, które obecnie są rozproszone i publikowane w różnorodnej formie. Informacje te mają wymiar wielofunkcyjny, wpływają na decyzje podmiotów publicznych, gospodarczych, przedsiębiorstw przemysłowych czy zwykłych obywateli. Odpowiednio uporządkowana wiedza o regionie może stać się impulsem do tworzenia terytorialnych form organizacji działalności gospodarczej. Głównym celem badań jest ocena wsparcia informacyjnego dla rozwoju społeczno-gospodarczego i przestrzennego oraz ocena metod monitorowania zmian społeczno-gospodarczych i przestrzennych, wspierających ideę zintegrowanego planowania. Autorzy prezentują w niniejszym artykule wyniki cząstkowych badań jakościowych podjętych przez B. Stelmach-Fitę w 2010 roku i kontynuowanych w poszerzonym zakresie od 2016 roku. Badania wspólne rozpoczęto od wywiadów z przedstawicielami urzędów marszałkowskich (odpowiedzialnych za planowanie rozwoju) i analiz portali. Następnie przeprowadzono badanie ankietowe skierowane do trzech jednostek 16 wymienionych urzędów. Autorzy wnioskują, że zidentyfikowane problemy wynikają z wadliwego stanu prawnego i proponują utworzenie nowego typu planu o cechach regulacyjno-operacyjnych dla obszaru całej gminy, wytycznych do sporządzania planu zagospodarowania przestrzennego województw. Wykazano możliwości technologiczne i organizacyjne udostępniania dodatkowych zbiorów danych przestrzennych, pod warunkiem dostosowania ich do wymagań regionalnych infrastruktur informacji przestrzennej oraz przygotowania i wprowadzenia odpowiednich mechanizmów prawnych. Istnieje potrzeba kontynuacji badań.
\end{abstract}

\begin{abstract}
In the paper we discuss the need to monitor and share information on socio-economic and spatial phenomena at the regional level, which is now published and disseminated in various forms. This information has a multi-functional dimension, affects the decisions of public and economic entities, industrial enterprises or citizens. Properly organised knowledge about the region can become an incentive for creating territorial forms of business organisation. The main objective of the research is the assessment of information support for socio-economic and spatial development, assessment of methods for monitoring socio-economic and spatial changes that support the idea of integrated planning. In the article, the authors present further results of partial qualitative research undertaken by co-author Stelmach-Fita in 2010 and continued together in an extended scope from 2016. The joint research began with interviews conducted with representatives of marshal offices (responsible for planning development) and portal analyses. A questionnaire was then sent to
\end{abstract}


three units of the 16 offices mentioned. The authors conclude that the identified problems arise from a flawed legal status and propose the creation of a new type of plan with regulatory and operational features for the entire municipality area, guidelines for drawing up spatial development plans for voivodeships. Technological and organisational possibilities of providing additional spatial data sets were demonstrated, provided they were adjusted to the requirements of Regional Spatial Information Infrastructures, as well as preparation and introduction of appropriate legal mechanisms. There is a need for further research development.

Słowa kluczowe: administracja publiczna; integracja danych; monitoring zmian społeczno-gospodarczych i przestrzennych; przedsiębiorcy; samorząd terytorialny

Keywords: data integration; entrepreneurs; local government; monitoring of socio-economic and spatial changes; public administration

Otrzymano: 24 maja 2018

Received: 24 May 2018

Zaakceptowano: 19 lipca 2018

Accepted: 19 July 2018

Sugerowana cytacja / Suggested citation:

Stelmach-Fita, B., Pękalska, M., Bartoszczuk, P. (2018). Usługi informacyjne w zakresie nowego zintegrowanego planowania jako czynnik determinujący rozwój przedsiębiorstw. Prace Komisji Geografii Przemysłu Polskiego Towarzystwa Geograficznego, 32(3), 216-236. https://doi.org/10.24917/20801653.323.14

\section{WSTĘP}

Współcześnie rozwijane badania w zakresie nauk związanych z rozwojem lokalnym podkreślają rolę terytorium jako czynnika determinującego rozwój przedsiębiorstw. Region postrzegany jest jako podstawowa płaszczyzna rozwoju społeczno-gospodarczego, a nawet jako nowy nurt badań regionalnych, związany z terytorialnymi formami organizacji działalności gospodarczej. Rezultatem rozwijających się dynamicznie badań regionalnych związanych z terytorium stało się przedefiniowanie pojęcia „terytorium”, pojmowanego nie jako geograficzna przestrzeń określona granicami administracyjnymi, lecz jako układ społeczno-instytucjonalny, cechujący się określonymi relacjami, wewnętrzną logiką i zorganizowaniem. Pisze o tym m.in. M. Słupińska (2014).

A. Jewtuchowicz (2014) wyjaśnia istotę pojęcia terytorium, identyfikuje problemy sterowania jego rozwojem, podkreślając wagę przepływu i sieci jako warunku bogactwa i władzy. M. Lackowska (2009) przewidziała nieuniknione nadejście w Polsce nowej ery współzarządzania - governance, które zostało zapoczątkowane w Stanach Zjednoczonych. Temat ten podejmowało w badaniach wielu kolejnych naukowców, takich jak chociażby A. Nowakowska (2014), która charakteryzuje governance jako „podkreślający sieciowy, partnerski, innowacyjny i procesowy charakter rozwoju. Współzarządzanie można więc rozumieć jako zbiór różnorodnych uwarunkowań, w których aktorzy tworzą swoje przestrzenie działania"1. Ponadto badacze widzą związek tworzenia nowych infrastruktur informacji przestrzennych z nowym nurtem zintegrowanego planowania.

Więcej szczegółów na ten temat przedstawiono w dalszej części artykułu, który został podzielony na dwie części. Pierwsza z nich przedstawia wyniki badań (w tym publikowane współautorki) od 2010 roku oraz przegląd literatury od 1998 roku, dotyczące specyfiki wspomnianych infrastruktur, zawężone do tematu INSPIRE zagospodarowanie przestrzenne, w kontekście jego potencjału dla tworzenia nowego modelu

\footnotetext{
${ }^{1}$ Można nawet te przestrzenie określić jako ich „światy produkcji” (Salais, Storper, 1993).
} 
zintegrowanego planowania w Polsce. Druga część artykułu prezentuje cząstkowe wyniki badań regionalnych, prowadzonych wspólnie z autorami tekstu w ramach zespołu naukowego od roku 2016.

W Planie na rzecz odpowiedzialnego rozwoju w części „Diagnoza” podkreśla się: „Polska potrzebuje nowego modelu rozwoju uwzględniającego jej unikalne zasoby środowiskowe. Średniookresowe wyzwania, płynące z uwarunkowań wewnętrznych, jak i otoczenia zewnętrznego, nakazują podjęcie działań dynamizujących rozwój społeczno-gospodarczy Polski. Ich istotą jest pełne wykorzystanie potencjału inwestycyjnego naszej gospodarki - w szczególności poprzez wzrost skali działań polskich firm, ich ekspansję zagraniczną, a także uruchomienie pokładów krajowej przedsiębiorczości i innowacyjności" (uchwała Rady Ministrów nr 14/2016: 2).

W diagnozie wskazywano na brak całościowej i długookresowej wizji rozwoju społeczno-gospodarczego Polski oraz faktycznej zdolności do horyzontalnej koordynacji działań administracji publicznej w celu konsekwentnej realizacji założonych priorytetów państwa. Polskie państwo musi nie tylko skutecznie wesprzeć polskie firmy w zwiększeniu innowacyjności ich oferty, co pozwoli im zdobyć klientów na bogatych, zaawansowanych rynkach, ale także samodoskonalić swoje procesy i usługi dla obywateli i przedsiębiorstw. Państwo powinno stać się dla polskich firm wymagającym technologicznie klientem. Nie ma bowiem innowacyjnej gospodarki bez innowacyjnego państwa.

Mimo stale rosnących kosztów ich funkcjonowania organy państwa nie realizują całościowych, jasno określonych celów rozwojowych. Jest to pułapka, która w dużej mierze pogłębia wszystkie pozostałe, gdyż to nieefektywne państwo jest w istotnym stopniu odpowiedzialne za brak impulsów pomnażających polski kapitał w gospodarce, niską innowacyjność, brak dążenia do konkurowania na poziomie wiedzy i jakości, a nie tylko na poziomie kosztów, a także za brak aktywnej polityki demograficznej. Nie bez powodu jakość instytucji publicznych jest uznawana we współczesnej ekonomii za kluczowy czynnik odpowiedzialny za długookresowe perspektywy rozwoju gospodarczego.

Celem polskiego rządu musi być zatem stymulowanie aktywności polskich firm, tak aby obecność zagranicznego kapitału wzmacniała perspektywy wzrostu gospodarczego. Wobec wyczerpania dotychczasowych czynników wzrostu Polska potrzebuje nowego modelu rozwoju gospodarczego. Odpowiedzialny rozwój powinien być oparty na pięciu filarach: reindustrializacji, rozwoju innowacyjnych firm, kapitale dla rozwoju, ekspansji zagranicznej, zrównoważonym rozwoju społecznym i regionalnym.

Rozproszone bazy danych i usługi sieciowe infrastruktury informacji przestrzennej (IIP) oraz krajowej infrastruktury danych przestrzennych (KIDP) uzupełniają te nowe struktury i wydaje się, że mogłyby wspierać politykę rozwoju w modelu planowania zintegrowanego i związanego z nim współzarządzania. 0 inteligencji danego terytorium świadczyć będzie, czy ten potencjał zostanie wykorzystany.

Głównym celem badań jest ocena wsparcia informacyjnego dla rozwoju społeczno-gospodarczego i przestrzennego, ocena metod monitorowania zmian społeczno-gospodarczych i przestrzennych wspierających ideę planowania zintegrowanego, w tym $\mathrm{z}$ wykorzystaniem infrastruktury informacji przestrzennej (w zakresie zagospodarowania przestrzennego).

Szczegółowe cele badań były następujące:

- ocena dostępu do wiarygodnych, kompletnych informacji, danych o zjawiskach społeczno-gospodarczych i przestrzennych, w tym porównywalnych dla 
wszystkich województw, które są potrzebne wielu użytkownikom, w tym inwestorom, do lokalizacji przedsiębiorstw,

- ocena wsparcia informacyjnego dla rozwoju społeczno-gospodarczego i przestrzennego na poziomie regionalnym ( $w$ tym jako impuls, czynnik determinujący rozwój przedsiębiorstw),

- ocena metod monitorowania polityki przestrzennej (integralny element rozwoju kraju),

- ocena podejścia do tworzenia regionalnych infrastruktur informacji przestrzennej w strukturach urzędów marszałkowskich w zakresie polityki przestrzennej.

Prezentowana część badań dotyczy następujących pytań badawczych:

1. Czy eksperci ds. foresight mają dostęp do wiarygodnych, kompletnych danych przestrzennych, np. związanych z potencjałem regionu czy presją inwestycyjną?

2. Czy problemy z brakiem jawnej polityki przestrzennej wynikają z wadliwego prawa?

3. Czy brak dostępu do informacji o polityce przestrzennej ma wpływ na rozwój regionu, w tym rozwój i lokalizację nowych przedsiębiorstw?

4. Czy istnieją problemy dotyczące kształtowania węzłów IIP w zakresie polityki przestrzennej, tematu danych INSPIRE „zagospodarowanie przestrzenne”?

5. Czy w Polsce w pełni wykorzystuje się potencjał regionalnych węzłów IIP, KIDP?

Zespół badawczy sformułował na tym etapie hipotezę, która dotyczy całościowych badań. Do czasu, kiedy programowanie strategiczne, w tym regionalne, będzie podporządkowane tylko zewnętrznym źródłom dofinansowania Unii Europejskiej, zamiast trafnym scenariuszom rozwoju (popartym eksperckimi diagnozami społeczno-ekonomicznymi), regiony nie będą miały możliwości dostrzec potencjału danego terytorium, a przez to nie będą mogły w pełni rozwijać się w sferze społeczno-gospodarczej i przestrzennej.

Ponadto Rada Infrastruktury Informacji Przestrzennej, 11 września 2017 dokonując przeglądu stanu IIP, zwróciła uwagę na kwestie związane z koniecznością udostępniania większej liczby usług sieciowych w obszarze zbiorów danych przestrzennych dotyczących ochrony środowiska oraz konwersji rozwiązań klasycznych (plików pdf) do postaci tych usług. Podkreślono, że tworzenie INSPIRE w Polsce to wiele działań, które mają przyczynić się do rozwoju kraju oraz sfery działalności publicznej i biznesowej. Za jeden z priorytetów uznano gospodarkę nieruchomościami i zagospodarowanie przestrzenne. Odnośnie do polityki metropolitalnej (miejskiej) pojawił się obecnie nowy kontekst ${ }^{2}$, wynikający z procesów globalizacyjnych, przyspieszającej urbanizacji i zmiany jej modelu.

\section{PRZEGLĄD LITERATURY I DOTYCHCZASOWYCH BADAŃ}

Poniżej przywołano tylko wybrane badania i literaturę od 1998 roku, związane z celem badań.

\section{Kontekst rozpoczętych reform zmiany systemu planowania przestrzennego}

Rozwój kreowany może być urzeczywistniany prawie wyłącznie poprzez planowanie (Chmielewski, 2008). W literaturze krytykuje się obecny stan prawny i dostrzega się potrzebę dokończenia rozpoczętych reform systemu planowania przestrzennego.

2 Nowa agenda miejska Habitat III 2016 i Miejska agenda UE (pakt amsterdamski). 
Zdecydowana obrona planowania przestrzennego w Polsce zaczęła się już od Arsenału IX w 1998 roku $^{3}$ i trwa do chwili obecnej. Coroczne raporty Instytutu Geografii i Przestrzennego Zagospodarowania PAN (IGiPZ PAN) na temat sytuacji planistycznej w gminach, zamawiane przez resort infrastruktury, wskazują, że poważnym problemem jest obejmowanie planami miejscowymi terenów stosunkowo niewielkich, niekiedy o powierzchni poniżej 1 ha (Śleszyński, Bański, Degórski, Komornicki, Więckowski, 2007; Śleszyński, Komornicki, Solon, Więckowski, 2012; Śleszyński i in., 2017) . W ten sposób plan miejscowy nie różni się zasadniczo od decyzji o warunkach zabudowy i zagospodarowania terenu (decyzji lokalizacyjnej). Zamiast pożądanych efektów kształtowania ładu przestrzennego prowadzi to do chaosu i rozlicznych dysfunkcji w lokalnych układach urbanistycznych (Gutry-Korycka, 2005; Kozłowski, 2006; Kistowski, 2007; Wdowicka, Mierzejewska, 2012; Kowalewski i in. 2014; Śleszyński 2015; Hołuj, Lityński, 2016; Źróbek-Różańska, Zysk, 2016; Stelmach-Fita, 2014; 2017; Śleszyński, Izdebski, Malinowski, Kursa, 2018).

Wydaje się, że najszybciej mógłby zostać wprowadzony zapis, zgodnie z którym plany miejscowe muszą np. obejmować całości funkcjonalne w postaci wsi, kwartałów zabudowy itp. Jeszcze bardziej restrykcyjny mógłby być zapis, aby minimalna powierzchnia planu nie była mniejsza od pewnej wartości lub liczby działek katastralnych (Śleszyński, Izdebski, Malinowski, Kursa, 2018). Badacze jednomyślnie potwierdzają, że obecny miejscowy plan nie jest efektywnym narzędziem kształtowania ładu przestrzennego.

\section{Kontekst - idea zintegrowanego planowania i potrzeba monitoringu}

O zintegrowanym planowaniu pisze m.in. T. Topczewska (2010) na podstawie badań prowadzonych przez Instytut Gospodarki Przestrzennej i Mieszkalnictwa w Warszawie (IGPiM), w których dokonano przeglądu systemów planowania w takich krajach UE, jak Niemcy, Francja, Wielka Brytania. Jak wskazano, „obok ustawowych (formalnych) regulacyjnych planów zagospodarowania przestrzennego (ogólnych i szczegółowych) - opracowywane są powszechnie pozaustawowe (nieformalne) zintegrowane plany rozwoju lokalnego i regionalnego. Zintegrowane plany rozwoju (...) są długookresowymi planami działania, na ogół o złożonym charakterze. Często mają formę planów strategicznych. Realizacja uzgodnionych działań zapewniona jest dzięki wprowadzeniu ich ustaleń do planów zagospodarowania przestrzennego. Miasta/gminy prowadzą politykę rozwoju społeczno-gospodarczego i przestrzennego w oparciu i zintegrowaną koncepcję rozwoju, opracowywaną w ramach planowania pozaustawowego, ale uzgodnioną ze społecznością lokalną i zgodną z celem, jakim jest zrównoważony, trwały rozwój itd. Zintegrowany sposób podejścia do planowania rozwoju miast zaleca Karta lipska4 2007.

Sprawdzone, w praktyce krajów UE zintegrowane plany i programy rozwoju powinny być wykorzystywane w strategicznym zarządzaniu polskimi miastami. Studium uwarunkowań i kierunków zagospodarowania przestrzennego nie jest planem rozwoju i nie może być instrumentem przydatnym do podejmowania decyzji w czasie (...)"

${ }^{3}$ Ogólnopolska Konferencja Planowania Przestrzennego - Arsenał IX, Wrocław, 9-10 listopada 1998 roku w Warszawie, która zebrała wszystkich praktyków, urbanistów, planistów cztery lata po wykreśleniu z nazwy ustawy planowania przestrzennego w 1994 roku. Mija już 20 lat pisania o negatywnych skutkach tego rozwiązania.

${ }^{4}$ Karta lipska na rzecz zrównoważonego rozwoju miast europejskich z 2007 roku. 
(Topczewska, 2010: 19-22). Dalej Topczewska pisze, że niezbędna jest integracja obu systemów planowania rozwoju i przestrzennego, polegająca na zdefiniowaniu roli i zadań poszczególnych planów i programów oraz wzajemne ich powiązaniu w obrębie i między poszczególnymi szczeblami planowania i zarządzania. Rozpoczęte reformy dotyczące integracji obydwu systemów nie zakończyły się.

Szczególnym wyzwaniem dla metodyki planowania zintegrowanego jest uwzględnienie czynnika czasu. Strategiczne planowanie zintegrowane powinno obejmować dłuższe okresy. W interwałach czasowych uwarunkowania i priorytety rozwoju przestrzennego mogą zmieniać się wielokrotnie. Monitoring zasobów przestrzeni jest szczególnie ważny.

A. Śliwiński (2008) z kolei zwraca uwagę na konieczność wprowadzenia w systemie planowania przestrzennego zapisów ściśle łączących wyniki monitoringu z działaniami planistycznymi prowadzonymi przez gminy. Zorganizowanie sprawnego systemu monitorowania przestrzeni wymusza powszechne stosowanie technologii GIS, w tym opartej na wolnym oprogramowaniu, oraz powiązane z tym ogromne zapotrzebowanie na usługi sieciowe.

Osobnym zagadnieniem jest monitorowanie danych ilościowych, różnych wskaźników, które są w Polsce dostarczane przez GUS. Propozycję istotnych i potrzebnych wskaźników zaproponował chociażby P. Śleszyński (2013) w ramach kompleksowej koncepcji wskaźników zagospodarowania i ładu przestrzennego.

Część badaczy (Schrank, Neuschmid, Petti, Wasserburger, 2011) widzi związek nowego podejścia do zintegrowanego planowania z powstawaniem w UE infrastruktury informacji przestrzennej. Jednak nie we wszystkich krajach UE potencjał tej infrastruktury jest wykorzystywany. Badania naukowe na temat potrzebnego monitoringu są prowadzone od dawna. 0 rekomendacjach dla monitoringu zagospodarowania przestrzennego piszą S. Annusz (2008) oraz w eksperckim opracowaniu A. Ciołkosz, E. Bielecka, E Kozubek i S. Anusz (2008). Autorzy tego artykułu zwracają szczególną uwagę na tę publikację, która zawiera potrzebne rekomendacje.

\section{Kontekst ogólny INSPIRE}

Podjęte w ostatnim czasie inicjatywy wspólnotowe generalnie miały przyczynić się do porządkowania systemu gromadzenia i przetwarzania danych przestrzennych ${ }^{5}$.

Naczelny cel norm (Parzyński, 2011) stosowanych w INSPIRE, jakim jest budowa

SDI (Spacial Data Infrastructure), jest osiągany za pomocą dwóch odmiennych i wzajemnie uzupełniających się strategii. Są one następujące:

1. strategia ukierunkowana na dane (data-centric view), polegająca na formułowaniu struktur danych w kategoriach modelowania pojęciowego, tj. jako schematy aplikacyjne i schematy metadanych,

2. strategia ukierunkowana na usługi (service-centric view), której istotą jest systematyka (taksonomia) usług, koncepcja współdziałania, struktur, katalogów.

Pierwsza strategia opiera się na koncepcji modelowej danych. Druga - na koncepcji geoportali, z których każdy będąc sieciowym systemem informacyjnym, stanowi ogniwo pośrednie pomiędzy zbiorem użytkowników - odbiorców usług a zbiorem serwerów dostarczających zarówno określone dane, jak i usługi.

\footnotetext{
${ }^{5}$ Dyrektywa 2003/98/WE Parlamentu Europejskiego i Rady w sprawie ponownego wykorzystywania informacji sektora publicznego (tzw. dyrektywy Re-use ), dyrektywa INSPIRE 2007/2/EC.
} 
Obydwie strategie wymagają opracowania modeli pojęciowych informacji w postaci sformalizowanych schematów aplikacyjnych, uniwersalnych i niezależnych od środowisk komputerowych. Głównym i podstawowym celem inicjatywy INSPIRE jest „uczynić odpowiednie i zharmonizowane dane geoprzestrzenne dostępnymi dla wspólnotowej polityki środowiskowej (opracowanie, zastosowanie, monitorowanie i ocena) i dla obywateli poprzez ustanowienie zintegrowanych usług w zakresie informacji geoprzestrzennej, opartych na sieciowo rozproszonych bazach danych, powiązanych wspólnymi standardami i protokołami dla zapewnienia technicznej zgodności” (Michalak, 2011).

Interoperacyjność w art. 3 dyrektywy INSPIRE definiuje się jako: „możliwość łączenia zbiorów danych przestrzennych oraz interakcji usług danych przestrzennych bez powtarzalnej interwencji manualnej, w taki sposób, aby wynik był spójny, a wartość dodana zbiorów i usług danych przestrzennych została zwiększona". Faza wdrażania, której realizacja rozpoczęła się w 2008 roku, ma trwać ponad 10 lat. Opracowanie Rady Infrastruktury Informacji Przestrzennej (Budowa infrastruktury informacji przestrzennej w Ministerstwie Transportu..., 2018) zawiera wiele ciekawych materiałów, które stanowią platformę wymiany informacji, ale niestety w zakresie tematu zagospodarowanie przestrzenne informacje te nie są aktualizowane. Wymieniono trzy funkcjonujące różne opracowania planistyczne przeznaczone do udostępniania w krajowej infrastrukturze informacji przestrzennej, nazywając je „dokumentami planistycznymi”.

W ramach IIP zaimplementowano w Polsce następujące usługi sieciowe:

- wyszukiwania - przeszukiwanie katalogów metadanych, zbiorów danych i danych;

- przeglądania - przeglądanie zwizualizowanych danych przestrzennych w kompozycji mapy zgodnie ze specyfikacjami;

- pobierania - pobieranie danych źródłowych lub zgeneralizowanych w formacie wektorowym (Geography Markup Language - GML);

- przekształcania - przetwarzanie informacji przestrzennej do standardów INSPIRE Usługa sieciowa (ang. web service) za W. Izdebskim (2016: 29-30) jest „realizowaniem potrzeb użytkownika poprzez sieć telekomunikacyjną (w tym sieć komputerową), a w szczególności przez internet. Usługa sieciowa jest w istocie składnikiem oprogramowania, niezależnym od platformy sprzętowej oraz implementacji, dostarczającym określoną funkcjonalność. Korzystając z usług sieciowych, można konstruować systemy rozproszone i aplikacje internetowe, które komunikują się przez sieć (...). Usługi sieciowe znalazły również szerokie zastosowanie w odniesieniu do danych przestrzennych". Na szczególną uwagę zasługuje pięć usług związanych z przeglądaniem i udostępnianiem tych danych:

1. $\mathrm{WMS}^{6}$ (ang. Web Map Service),

2. WMTS (ang. Web Map Tile Sercvice),

3. WFS (ang. Web Feature Service),

4. WCS (ang. Web Coverage Service),

5. CSW (ang. Catalogue Service for Web).

${ }^{6}$ WMS - Web Map Service to międzynarodowy standard udostępniania danych przestrzennych w internecie w postaci rastrowej. WCS - Web Coverage Service to usługa udostępniająca dane najczęściej w formie rastrowej. Warstwami są ciągłe dane przestrzenne, takie jak zdjęcia lotnicze i satelitarne, dane o pokryciu i wysokości terenu, których zmienność przestrzenna reprezentowana jest za pomocą pokryć rastrowych. WFS - usługa pobierania danych przestrzennych Web Feature Service umożliwia pobranie części lub całości poszczególnych zbiorów danych przestrzennych przechowywanych zgodnie z zadanymi kryteriami. 
Jedną z najważniejszych usług sieciowych związanych z danymi przestrzennymi jest WMS, która służy do udostępniania map w postaci rastrowej za pomocą interfejsu http i jest dzisiaj podstawą publikacji danych przestrzennych w internecie. Usługi przeglądania są przeznaczone dla wszystkich obywateli UE. Usługi pobierania są przeznaczone dla węższej grupy użytkowników. Usługa przeglądania jest popularna we Francji i Holandii jako praktyczne narzędzie, np. do opiniowania, uzgadniania planów, dokumentów przez różne branże. Nie ma potrzeby przekazywania dokumentów drogą pocztową czy e-mailową.

Zgodnie z wymaganiami rozporządzenia Komisji (UE) nr 1089/2010, „aby zapewnić interoperacyjność i harmonizację między tematami danych przestrzennych, państwa członkowskie powinny spełnić wymagania dotyczące wspólnych typów danych, identyfikacji obiektów przestrzennych (...)".

\section{Kontekst czasowy i temat zagospodarowania przestrzennego}

Dyrektywa INSPIRE odnosi się wprost do danych o obecnym i przyszłym zagospodarowaniu przestrzennym. Model tematu uwzględnia czynnik czasu i w specyfikacji (D2.8.III.4 Data Specification..., 2015) wyróżnia: „istniejące zagospodarowanie przestrzenne - Existing Land Use (ELU) i planowane zagospodarowanie przestrzenne Planned Land Use (PLU) - wynikające z dokumentów planistycznych. Łączy je wspólna, obowiązująca wszystkie kraje UE klasyfikacja HILUCS, oznaczająca wielopoziomowy system klasyfikacji kategorii zagospodarowanie przestrzenne i którą obowiązkowo należy stosować na najbardziej odpowiednim poziomie hierarchii. Zbiory danych tutaj zamieszczane na europejskim poziomie IIP muszą spełniać wymagania specyfikacji Land Use" (Stelmach-Fita, 2014).

Wybór skali pozostawia się dostawcy zbiorów. Zależy ona od minimalnej jednostki (MUI) rozpatrywanej w zbiorze danych ELU. Natomiast wybór skali dotyczący PLU zależy od typu planu, a ponadto - w przypadku planów strefowych - od minimalnego elementu strefowego (zoning element) rozpatrywanego w danym zbiorze danych.

Ryc. 1. ELU i PLU wraz ze schematami aplikacji

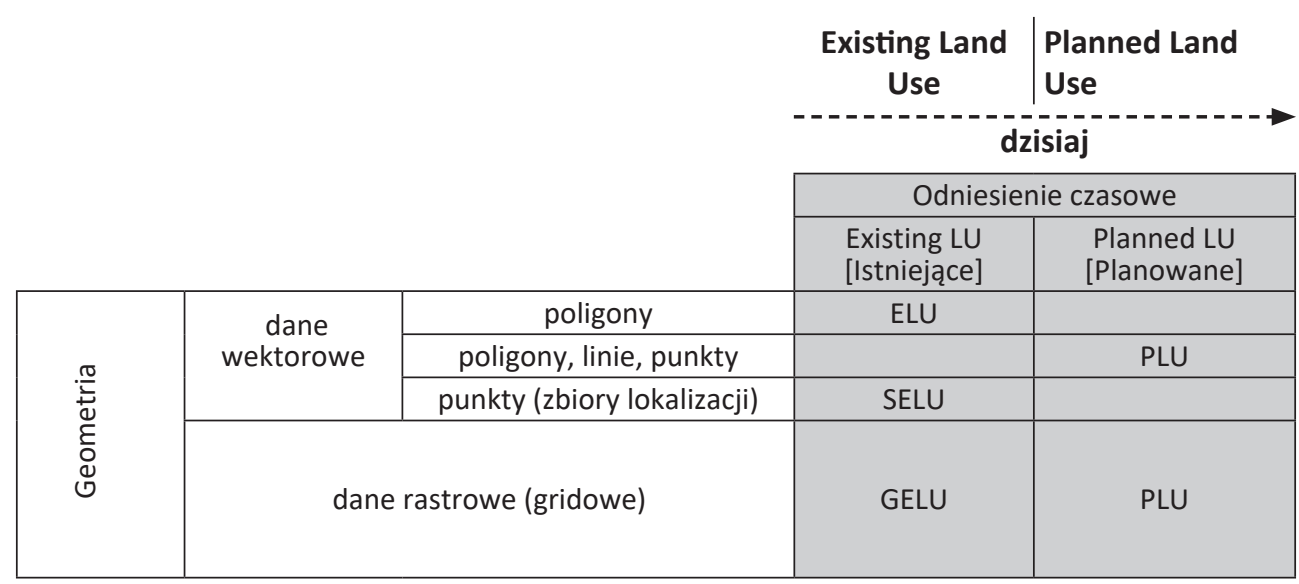

Źródło: opracowanie własne na podstawie Stelmach-Fita (2014) 
Jedynym typem planu w Polsce mającym cechy dokumentu operacyjnego jest bardzo szczegółowy miejscowy plan zagospodarowania przestrzennego, dlatego cała uwaga badaczy w Polsce w ostatnich latach skupiała się na standaryzacji tego planu.

B. Stelmach-Fita prowadziła badania jakościowe w latach 2010-2012 dotyczące identyfikacji problemów związanych z implementacją wytycznych INSPIRE w zakresie zagospodarowania przestrzennego. Wnioski i rekomendacje z tych badań są nadal aktualne, jeśli chodzi o potrzebę zdefiniowania dokumentu planistycznego, utworzenia nowego typu planu regulacyjno-operacyjnego lub wzmocnienia roli studium uwarunkowań i kierunków zagospodarowania przestrzennego (suikzp), a także o rekomendacje dla standaryzacji tego dokumentu lub miejscowego planu ogólnego dla całej gminy. Wyniki badań autorka zaprezentowała w kilku publikacjach (Stelmach-Fita, 2011; 2014; 2016; 2017).

W opinii autorki wytyczne specyfikacji sprawdzają się najlepiej dla dużych jednostek strefowych - planów strefowych, planów ogólnych, a nie dla małych jednostek terenowych polskich miejscowych planów czy decyzji lokalizacyjnych (np. decyzji o warunkach zabudowy i zagospodarowania terenu), innych decyzji specjalnych (większość inwestycji liniowych). Jej zdaniem intencją autorów specyfikacji było połączenie planowania społeczno-gospodarczego z planowaniem przestrzennym, dla którego najważniejszą płaszczyzną zintegrowanego planowania, jest obszar co najmniej jednej gminy, subregion, region.

B. Stelmach-Fita (2014; 2016; 2017), po analizie udostępnionych jej w maju 2011 roku wyników zamówienia Biura Geodety Województwa Mazowieckiego - „Projektu standardowych modeli danych oraz profilu metadanych dla opracowań planistycznych", wykazała, że autorom projektu bardzo trudno było sformułować definicję „dokumentu planistycznego" w obowiązującym stanie prawnym. Odniosła się do autorskiej oceny P. Malczewskiego (2015) przedstawionej podczas prezentacji IGPiM w 2013 roku, zgadzając się z jej ogólnymi wnioskami. Odnośnie do opracowania UNEP/GRID Warsaw (Budowa infrastruktury informacji przestrzennej w Ministerstwie Infrastruktury..., 2018), Stelmach-Fita (2016) potwierdza za Malczewskim (2015) brak zasadności wprowadzania obowiązku „wektoryzacji zasobu obowiązującego, w celu doprowadzenia go do postaci umożliwiającej włączenie do zasobu IIP jako zbiorów danych na poziomie klas obiektów, ze względu na wykorzystanie tu niezestandaryzowanych obiektów referencyjnych". W Europie stosuje się dobrowolnie strategie zniekształcania, przetwarzania planów, ale nie w każdym przypadku i tylko do celów zasilania baz danych SIP danymi, a nie jako interpretacja wytycznych wspomnianej specyfikacji INSPIRE „Land Use”.

Standaryzacja zapisu miejscowego planu zagospodarowania przestrzennego (mpzp) jest kwestią drugorzędną, a nawet niemożliwą do zrealizowania w obecnym stanie prawnym, w którym zgodnie z techniką legislacyjną każdy miejscowy plan może zawierać swoje, własne definicje. $\mathrm{W}$ związku z tym sytuacja zrobiła się patowa, jeżeli chodzi o wybór dokumentu planistycznego, jaki powinien być udostępniany na poziomie europejskim do potrzeb monitorowania zmian w porównywalnych jednostkach przestrzennych dla wsparcia polityki ochrony środowiska.

Stosownie do opisu w specyfikacji danych „Land Use”, zbiory danych obecnego zagospodarowania terenu - Existing Land Use (ELU) - mogą być pozyskiwane z kilku źródeł. 
Na krajowym geoportalu (w serwisie geoportal.gov.pl) w tym zakresie m.in. dostępne są bazy danych obiektów topograficznych, aktualizowane co sześć lat. Są to ciekawe zbiory, ale mało dokładne i stanowią tylko jedno z kilku źródeł danych. Do analiz przestrzennych potrzebne są zbiory danych z innymi kategoriami i częściej aktualizowane, jak chociażby European Urban Atlas - Europejski Atlas Miejski. Jest to standard bazy typu „Land Use” wykonywany na zamówienie Dyrekcji Generalnej DG REGGIO Komisji Europejskiej o 20 klasach użytkowania. Urban Atlas dostarcza paneuropejskich porównywalnych danych dotyczących użytkowania gruntów i pokrycia terenu dla dużych stref miejskich z ponad 100 tys. mieszkańców, zgodnie z definicją Urban Audit. Dane GIS można pobrać razem z mapą dla każdego obszaru miejskiego objętego raportem i raportem z metadanymi (Urban Atlas, 2018). Baza jest dostępna w postaci usługi WMS.

Tab. 1. Atlas miejski

\begin{tabular}{|c|c|c|}
\hline L.p. & URBAN ATLAS & ATLAS MIEJSKI \\
\hline 1 & Continuous Urban fabric & Zwarta zabudowa miejska \\
\hline 2 & Discontinuous Dense Urban Fabric & Niezwarta zabudowa miejska \\
\hline 3 & Discontinuous Medium Density Urban Fabric & Średniej gęstości niezwarta zabudowa miejska \\
\hline 4 & Discontinuous Low Density Urban Fabric & Niskiej gęstości niezwarta zabudowa miejska \\
\hline 5 & Discontinuous very low density urban fabric & $\begin{array}{l}\text { Bardzo niskiej gęstości niezwarta zabudowa } \\
\text { miejska }\end{array}$ \\
\hline 6 & Isolated Structures & Odizolowane struktury przemysłowe \\
\hline 7 & $\begin{array}{l}\text { Industrial, commercial, public, military and } \\
\text { private units }\end{array}$ & $\begin{array}{l}\text { Jednostki przemysłowe, handlowe, (publiczne, } \\
\text { wojskowe i prywatne jednostki) }\end{array}$ \\
\hline 8 & Fast transit roads and associated land & Drogi szybkiego ruchu z terenami przyległymi \\
\hline 9 & Other roads and associated land & Inne drogi z terenami przyległymi \\
\hline 10 & Railways and associated land & Koleje z terenami przyległymi \\
\hline 11 & Port areas & Tereny portów \\
\hline 12 & Airports & Porty lotnicze \\
\hline 13 & Mineral extraction and dump sites & Tereny złóż mineralnych i ich zrzutów \\
\hline 14 & Construction sites & Tereny budów \\
\hline 15 & Land without current use & Tereny aktualnie nieużytkowane \\
\hline 16 & Green urban areas & Tereny zieleni miejskiej \\
\hline 17 & Sports and leisure facilities & Tereny udogodnień sportowych i rekreacji \\
\hline 18 & Agricultural, semi-natural and wetland areas & Tereny rolnicze, naturalne i bagienne \\
\hline 19 & Forest & Tereny lasów \\
\hline 20 & Water & Tereny pokryte wodą \\
\hline
\end{tabular}

Źródło: opracowanie własne na podstawie specyfikacji D2.8.III.4 Data Specification (2015)

\section{Kontekst - inteligentne miasto, metropolia, region}

Szanse na budowanie inteligentnego miasta zapewniają również zapisy dotyczące inteligentnego rozwoju w długo- i średnioterminowej strategii rozwoju na poziomie krajowym7, jak zauważa D. Sikora-Fernandez (2018). Obejmują one budowę

7 „Długookresowa strategia rozwoju kraju: Polska 2030. Trzecia fala nowoczesności” (DSRK) i „Średniookresowa strategia rozwoju kraju” wraz z „Koncepcją przestrzennego zagospodarowania kraju” stanowią ramę nowego porządku strategicznego w perspektywie do 2030 roku. 
zautomatyzowanych systemów kontroli lotów, inteligentne systemy transportowe, lepszą komunikację z administracją publiczną oraz zwiększoną efektywność w projektach energetycznych (Sikora-Fernandez, 2018; Bereskova, Nijkamp, 2018). Omawiane tu zagadnienia dotyczą nie tylko smart city (inteligentnych miast), ale również smart metropolia (inteligentnych metropolii) czy smart region (inteligentnych regionów) ze względu na różnego rodzaju wzajemne powiązania sieciowe inicjowane przez Civitas (tkankę społeczną).

\section{WYNIKI WSPÓLNYCH BADAŃ ZESPOŁU - OD 2016 ROKU}

\section{Wyniki badań jakościowych - wywiady i analiza portali}

Badania podjęte w 2016 roku przez zespół naukowców z trzech polskich uczelni wykazały niewystarczający monitoring zjawisk, procesów społeczno-gospodarczych i przestrzennych na poziomie regionalnym. Współautorzy opisali wyniki wywiadów i analiz geoportali regionalnych obserwatoriów terytorialnych w publikacji z 2017 roku (Stelmach-Fita, Bartoszczuk, Pękalska, 2017). Odnośnie do monitoringu na poziomie regionalnym uwaga została skupiona na monitorowaniu wskaźników zawartych w strategiach (zebranych w systemie STRATEG GUS, 2018), w tym przede wszystkim do rozliczeń środków finansowych zewnętrznych. Pozytywnie ocenia się kwestię rozbudowy Banku danych lokalnych.

Zwrócono uwagę na niewykorzystany potencjał regionalnych obserwatoriów terytorialnych (ROT), które w założeniu miały tworzyć zestandaryzowany bank danych o regionie dla różnego typu odbiorców, w tym dla zarządzających danym terytorium, urbanistów, przedsiębiorców, polityków, środowiska naukowe. Pytaniem otwartym jest, czy ROT są zainteresowane poszerzaniem swoich kompetencji w zakresie współpracy z jednostkami planistycznymi, jednostkami udostępniającymi dane przestrzenne, odpowiadającymi za węzły IIP, IDP.

W Polsce obserwuje się brak kompleksowego podejścia do konstruowania od podstaw krajowej infrastruktury danych przestrzennych. Nie rozstrzygnięto kwestii sposobu wizualizacji, powiązania z infrastrukturą wszystkich danych przestrzennych wynikających z decyzji warunkujących zagospodarowanie przestrzenne (zawartych w rejestrach publicznych). Autorzy zwracają uwagę na potencjał budowy takiej infrastruktury na poziomie regionalnym w powiązaniu z poziomem powiatowym (przy wsparciu powiatowych ośrodków dokumentacji geodezyjnej i kartograficznej - PODGiK). Główna uwaga w odniesieniu do monitorowania zmian w zagospodarowaniu przestrzennym powinna być skupiona na monitorowaniu porównywalnych stref ustanowionych dla obszaru gminy, spójnych z europejską klasyfikacją HILUCS (Hierarchical INSPIRE Land Use Classification System).

\section{Baza danych przestrzennych na poziomie regionalnym - metropolia Poznań}

W 2015 roku, na zlecenie Stowarzyszenia Metropolii Poznań, Centrum Badań Metropolitalnych Uniwersytetu im. Adama Mickiewicza w Poznaniu przygotowało Koncepcję kierunków rozwoju przestrzennego metropolii Poznań (Mikuła, Kaczmarek, Gadziński, Bul, 2016). Opracowanie zostało wskazane do realizacji w dokumencie Stowarzyszenia Metropolii Poznań pt. Strategia rozwoju aglomeracji poznańskiej. Metropolia Poznań 
Ryc. 2. Cele powstania jednorodnej bazy danych przestrzennych metropolii Poznań

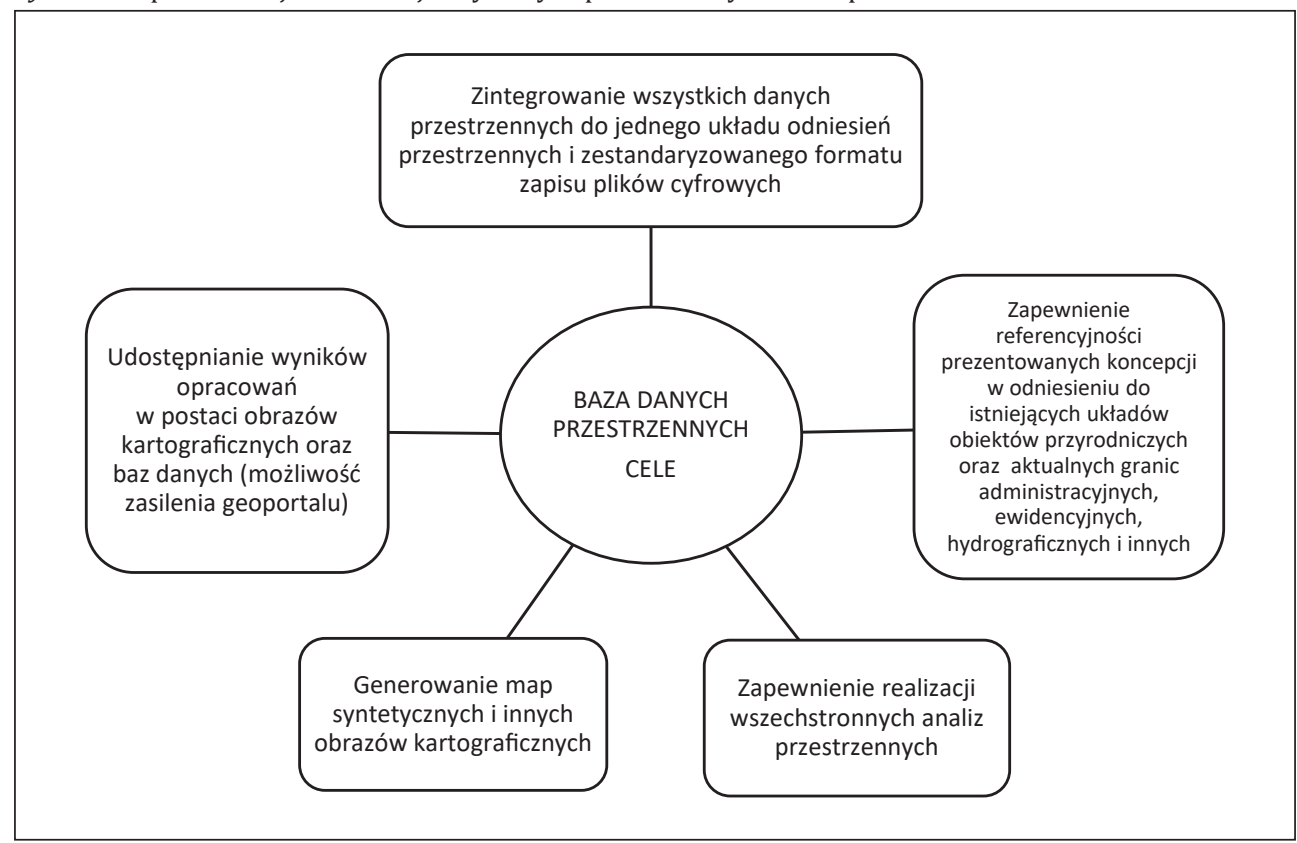

Źródło: Koncepcja kierunków... (2015: 21)

2020. Jego celem jest „przedstawienie spójnej, zdefiniowanej obszarowo i promującej zintegrowane podejście do rozwiązywania problemów rozwojowych koncepcji kierunków rozwoju przestrzennego metropolii oraz opracowanie zasad wdrażania ustaleń koncepcji do suikzp gmin oraz mpzp (Koncepcja kierunków..., 2015). Na obszar metropolii Poznań składają się 22 gminy, w większości miejsko-wiejskie.

Na potrzeby realizacji koncepcji powstała baza danych przestrzennych metropolii Poznań. Cele stworzenia bazy danych zdefiniowane przez autorów koncepcji zostały przedstawione na schemacie poniżej. Uspójnione dane przestrzenne mają pozwolić na stworzenie cyfrowych obrazów przestrzennych metropolii, które później mogłyby być udostępniane na geoportalu. Najistotniejsze elementy koncepcji będą mogły być udostępniane publicznie za pośrednictwem usług sieciowej WMS i stać się elementem krajowej infrastruktury informacji przestrzennej. rów:

Baza danych przestrzennych metropolii Poznań składa się z dwóch głównych zbio-

- danych źródłowych - są to zasoby pozyskane z urzędów i instytucji, elementy polskiej infrastruktury informacji przestrzennej, przetworzone do jednego formatu (shp, GeoTIFF) oraz przetransformowane do jednego układu współrzędnych PL1992;

- opracowań autorskich - zasoby danych przestrzennych wytworzone przez autorów koncepcji (zbiory danych wektorowych).

Do stworzenia zbioru pierwszego wykorzystano cyfrowe bazy danych wymienione $\mathrm{w}$ tab. 2. Innymi materiałami o charakterze uzupełniającym były: zasoby archiwalnych materiałów kartograficznych w postaci rastrowej (mapy topograficzne, mapy tematyczne), dane przestrzenne w postaci usługi sieciowej WMS, udostępniane 
w internecie przez ich dysponentów, bazy danych sporządzane na potrzeby wykonania opracowań planistycznych np. STUDIUM (Koncepcja kierunków..., 2015: 23). Autorzy koncepcji za najtrudniejsze przy tworzeniu bazy danych przestrzennych metropolii Poznań uznają „zapewnienie jednolitej i spójnej referencji przestrzennej rozpatrywanych obiektów i zjawisk", co umożliwia bezpośrednie odniesienie wyników projektu do innych elementów infrastruktury informacji przestrzennej. Ujednolicenie i uspójnienie przestrzenne danych jest w opracowaniu rozumiane jako: „przyjęcie jednorodnego, poprawnego topologicznie podziału terenu na naturalne (przyrodnicze) i sztuczne (np. administracyjne) jednostki przestrzenne”, oraz „zagwarantowanie zgodności danych z obowiązującymi podziałami kraju na jednostki przestrzenne, systemami identyfikatorów oraz zastosowanie państwowego układu odniesień" (Koncepcja kierunków, 2015: 23).

Tab. 2. Referencyjne bazy danych przestrzennych wykorzystane w opracowaniu

\begin{tabular}{|l|l|l|}
\hline \multicolumn{1}{|c|}{ Nazwa } & \multicolumn{1}{|c|}{ Dysponent } & \multicolumn{1}{c|}{$\begin{array}{c}\text { Skala nominalna/ układ } \\
\text { współrzędnych }\end{array}$} \\
\hline Państwowy Rejestr Granic (PRG) & Główny Geodeta Kraju & $1: 5000$ / PL-1992 \\
\hline $\begin{array}{l}\text { Państwowy Rejestr Nazw } \\
\text { Geograficznych (PRNG) }\end{array}$ & Główny Geodeta Kraju & $1: 10000 /$ PL-1992 \\
\hline $\begin{array}{l}\text { Baza danych ogólnogeograficznych } \\
\text { (BD0250GIS) }\end{array}$ & Główny Geodeta Kraju & $1: 250000 /$ PL-1992 \\
\hline $\begin{array}{l}\text { Baza danych obiektów } \\
\text { topograficznych (BDOT10k) }\end{array}$ & $\begin{array}{l}\text { Wojewódzki Ośrodek } \\
\text { Dokumentacji Geodezyjnej } \\
\text { i Kartograficznej }\end{array}$ & $1: 10000 /$ PL-1992 \\
\hline $\begin{array}{l}\text { Numeryczny model terenu } \\
\text { (NMT100) }\end{array}$ & Główny Geodeta Kraju & $1: 10000 /$ PL-1992 \\
\hline $\begin{array}{l}\text { Ewidencja gruntów i budynków } \\
\text { (EGiB) }\end{array}$ & $\begin{array}{l}\text { Powiatowe ośrodki dokumentacji } \\
\text { geodezyjnej i kartograficznej }\end{array}$ & $1: 5000$ / PL-2000 \\
\hline Leśna mapa numeryczna (LMN) & Lasy Państwowe & $1: 5000$ / PL-1992 \\
\hline $\begin{array}{l}\text { Mapa podziału hydrograficznego } \\
\text { Polski (MPHP) }\end{array}$ & $\begin{array}{l}\text { Krajowy Zarząd Gospodarki } \\
\text { Wodnej }\end{array}$ & $1: 100000$ / PL-1992 \\
\hline
\end{tabular}

Źródło: Koncepcja kierunków... (2015: 22)

\section{Baza wiedzy o regionie - wyniki badania dotyczące regionalnych węzłów IIP}

Potrzeba podjęcia badań na temat bazy wiedzy o regionie wynika zarówno z problemów rynkowych, jak i teoretycznych, sygnalizowanych przez praktyków i naukowców zajmujących się m.in. planowaniem przestrzennym ${ }^{8}$. Mierniki oceny zmian w rozwoju, teoretyczne podstawy badań typu foresight w kontekście społeczno-gospodarczym i przestrzennym, metodologię badań (ideę „banku informacji o regionie”, genezę powstania i zakres ankiety badawczej) rozpoczętych w 2016 roku, opisano we wcześniejszej publikacji (Stelmach-Fita; Brodowicz, 2017). Przywołano specyfikę raportów dotyczących sytuacji społeczno-ekonomicznej, opracowywanych przez właściwe

\footnotetext{
${ }^{8}$ Do zainteresowania problematyką badawczą zachęcił autorów J. Korzeń (członek Rady Towarzystwa Urbanistów Polskich) po wygłoszeniu referatu na konferencji z 24-25 września 2015 roku „Ekologia konstruktywnie”, w którym mówił o modzie na opracowywanie strategii rozwoju i problemach przełożenia ich celów na opracowania planistyczne.
} 
Ministerstwo Rozwoju (obecnie inna nazwa) ${ }^{9}$ oraz przez Główny Urząd Statystyczny. Niektóre zagadnienia uzupełniają się, a inne powtarzają. Na jednej ze stron GUS - „Portal geostatystyczny” https://geo.stat.gov.pl/imap/) znajduje się wiele cennych danych, które - po odpowiednim przetworzeniu w analizach typu GIS - można wykorzystać, ale nie ma tu zbiorów danych przestrzennych (z metadanymi i informacjami o georeferencji) dostępnych w usługach sieciowych WMS, WCS, WFS, o których mowa w dyrektywie INSPIRE.

Badanie empiryczne rozpoczęto od wywiadów pogłębionych z przedstawicielami regionalnych obserwatoriów terytorialnych w czterech województwach. Zakres pytań ankiety zaprezentowano na spotkaniu z przedstawicielami Departamentu Strategii Rozwoju Ministerstwa Rozwoju 13 grudnia 2016 roku, a następnie przedyskutowano na spotkaniach z przedstawicielami ROT w dniach 15 i 16 grudnia 2016 roku.

Ankietę pt. Baza danych opisowych i przestrzennych o regionie, datowaną na 1 czerwca 2017 roku, opracowaną przez koordynatora zespołu badawczego i zaopiniowaną przez pozostałych członków zespołu (cztery osoby) ${ }^{10}$, w skład którego wchodzą przedstawiciele trzech uczelni (Uniwersytet Pedagogiczny w Krakowie, Szkoła Główna Handlowa w Warszawie, Uniwersytet Warszawski) przesłano do wszystkich marszałków - e-mailem i w wersji papierowej. Ankieta na samym początku zawiera pytania dotyczące liczby (trzech typów) wydawanych decyzji warunkujących zagospodarowanie przestrzenne zawartych w rejestrach w latach 2012-2016.

Następne grupy pytań zostały podzielone na trzy części - A, B, C, kierowane do następujących jednostek:

- A - infrastruktura informacji przestrzennej lub infrastruktura danych przestrzennych,

- B - Biuro Planowania Przestrzennego - polityka przestrzenna na poziomie regionalnym,

- C - regionalne obserwatorium terytorialne - baza danych społeczno-gospodarczych i przestrzennych o regionie.

Poniżej przybliżono zakres pytań i wyników części A skierowanej do jednostek IIP. Na 16 województw napłynęły odpowiedzi od 14 przedstawicieli (pisemnie) oraz jednego telefonicznie.

Na pytanie: Czy regionalny węzeł IIP/IDP zawiera plan zagospodarowania przestrzennego województwa (PZPW)? odpowiedzi były różne. Pięć osób wskazywało na udostępnienie w ramach IIP, były dwie odpowiedzi „nie” bez komentarza oraz siedem odpowiedzi „nie” z uzasadnieniem, że nie ma wytycznych ani przepisów w tym zakresie, a dane są dostępne w Biuletynie Informacji Publicznej (BIP).

„Brak przepisów odnośnie [do] kompetencji i praw marszałka do udostępniana danych zawartych w planach wojewódzkich, pochodzących z wielu źródeł posiadających wielu dysponentów, udostępniających własne dane na różnych zasadach licencyjnych" (dolnośląskie).

${ }^{9}$ Raport „Przegląd Regionalny”, ukazujący się co dwa lata - analiza sytuacji województwa w obszarze oddziaływania Europejskiego Funduszu Społecznego przez regionalne obserwatoria terytorialne; Raport o rozwoju społeczno-gospodarczym, regionalnym oraz przestrzennym obejmujący rok 2014.

${ }^{10}$ B. Stelmach-Fita, Uniwersytet Pedagogiczny w Krakowie (koordynator), P. Bartoszczuk, Szkoła Główna Handlowa, D. Brodowicz, Szkoła Głowna Handlowa, M.P. Pękalska, Uniwersytet Warszawski. 
„Pomimo wskazanych powyżej w punktach a i b przyczyn publikacja PZPW jest planowana" (łódzkie).

„Brak jest regionalnego węzła IIP/IDP. W ramach II funkcjonuje regionalny system informacji przestrzennej województwa lubuskiego (RSIPWL), gdzie dane udostępniane są za pomocą usług danych przestrzennych WMS ${ }^{11}$. Portal RSIPWL zawiera PZPW. W BIP umieszczona jest informacja o RSIPWL” (lubuskie).

„Plan zagospodarowania województwa małopolskiego jest na stronie http://malopolska.pl. Obecna aktualizacja PZPW jest na etapie uzgodnień. Po jego uchwaleniu plan zostanie opublikowany w regionalnym węźle infrastruktury informacji przestrzennej ${ }^{12 ”}$.

„Plan jest udostępniony na portalu mapowym MSIP za pośrednictwem WMS i WFS oraz Plan na stronie BIP" (mazowieckie).

„Plan jest udostępniany w formie WMS” (opolskie).

„Problemem nie jest brak konkretnych przepisów wskazujących na obowiązek udostępniania planów zagospodarowania przestrzennego w ramach infrastruktury informacji przestrzennej, lecz przede wszystkim brak wytycznych technicznych, dotyczących ich sporządzania” (śląskie). „Projekt Podkarpacki System Informacji Przestrzennej (PSIP), który jest obecnie realizowany, będzie zawierał komponent umożliwiający publikację przedmiotowego planu (podkarpackie). Niezależnie od tego treść planu oraz jego załączniki udostępnione są na stronie BIP i na stronie jednostki organizacyjnej samorządu, odpowiedzialnej za sporządzenie dokumentu. Brakuje sformalizowanego węzła informacji przestrzennej na poziomie regionalnym - jest on w trakcie realizacji koncepcji” (pomorskie).

„Urząd Marszałkowski Województwa Wielkopolskiego jest na etapie budowy i wdrożenia Systemu Informacji Przestrzennej Województwa Wielkopolskiego (SIPWW). W ramach geoportalu SIPWW będą udostępniane różne informacje przestrzenne, tworzone na poziomie wojewódzkim, w tym PZPW. Wszystkie realizowane $\mathrm{w}$ projekcie dane przestrzenne będą dostępne nieodpłatnie poprzez usługi danych przestrzennych wyszukiwania i przeglądania, zgodnie z ustawą o infrastrukturze informacji przestrzennej (art. 12). Przetworzone do postaci cyfrowej zasoby danych przestrzennych i aktualizowane na bieżąco wojewódzkie bazy danych, rejestry i opracowania tematyczne na poziomie wojewódzkim będą uzupełniały i zasilały inne rejestry i bazy danych na różnych poziomach administracji” (wielkopolskie).

„Brak IIP, etap wdrażania” (zachodniopomorskie).

„PZPW udostępniany jest jako usługa WMS” (podlaskie).

„PZPW jest udostępniany na stronie www.atlas.warmia.mazury.pl” (warmińsko-mazurskie).

\section{Weryfikacja wyników badania w wywiadach z ekspertami i specjalistami}

Wyniki badań poddano dyskusji 23 czerwca 2018 roku podczas jednego z comiesięcznych spotkań urbanistów w ramach Komisji ds. Planowania Przestrzennego ${ }^{13}$ działającej przy oddziale warszawskim Towarzystwa Urbanistów Polskich (TUP).

\footnotetext{
${ }^{11}$ Adres portalu: http://www.rsipwl.lubuskie.pl/.

${ }^{12}$ Czyli na stronie Małopolskiej Infrastruktury Informacji Przestrzennej, dostępnej pod adresem http:// miip.geomalopolska.pl.

${ }^{13}$ Komisja ds. planowania przestrzennego TUP funkcjonuje od kwietnia 2018 roku.
} 
Odnośnie do stanu prawnego, strategiczne planowanie powinno obejmować dłuższe okresy, np. 25-30 lat. W warunkach gospodarki rynkowej i globalizacji nie ma możliwości przewidzenia kierunków i skali tych zmian. Odpowiedzią na to może być wyłącznie planowanie kroczące. Konieczne są wieloletnia prognoza finansowa, wieloletni plan inwestycyjny oraz ewentualnie, dyskutowany obecnie, miejscowy plan ogólny dla obszaru całej gminy.

10 lipca 2018 roku przeprowadzono wywiad z Z. Malinowskim, prezesem firmy Geo-System Sp. z o.o. z Warszawy (która przetworzyła do postaci numerycznej plany miejscowe dla ok. 800 urzędów gmin). Poproszono go o opinię na temat usług sieciowych (przestrzennych) i zbiorów danych przestrzennych dotyczących regionalnych węzłów IIP. Oto jej treść:

„Poddając bardziej szczegółowej analizie regionalne węzły IIP, można sporadycznie spotkać się ze zjawiskiem przekraczania swoich kompetencji (np. opolskie w zakresie udostępniania miejscowych planów, łódzkie w zakresie EGIB ${ }^{14}$ ). Marszałek powinien udostępniać te zbiory danych, za które odpowiada, natomiast zbiory z poziomu lokalnego (powiat/gmina) należy integrować poprzez usługi sieciowe (np. WMS czy WFS) bezpośrednio z ich źródła. Próba zawłaszczenia przez marszałków kompetencji gmin i powiatów będzie skutkować tym, że w geoporalu regionalnym będą nieaktualne kopie danych, do których nie będzie można mieć zaufania.

Odnośnie do zlecania przez gminy cyfryzacji, przetwarzania opracowań planistycznych, na 776 gmin zdecydowana większość (80\%, czyli 618 gmin) zleca udostępnianie mpzp w postaci rastrowej, a 20\% (czyli 158 gmin) zleca przetwarzanie i udostępnianie ich w wersji wektorowej".

Z. Malinowski podkreślił jednak, że jego zdaniem największy problem stanowi obecnie wręcz archaiczny przepis zawarty w art. 16 ustawy z dnia 27 marca 2003 roku o planowaniu i zagospodarowaniu przestrzennym ${ }^{15}$, który powinien być dawno znowelizowany, spójny z dynamicznie aktualizowaną ustawą z dnia 17 maja 1989 roku - Prawo geodezyjne i kartograficzne. W przepisie powinno być odniesienie do wykorzystania danych ewidencyjnych w postaci numerycznej, a nie kopii map.

\section{DYSKUSJA I WNIOSKI}

Obecne problemy wynikają z wadliwego stanu prawnego, utrudniającego utworzenie dwóch profili metadanych dla: istniejącego zagospodarowania przestrzennego (Existing Land Use) i planowanego zagospodarowania przestrzennego (Planned Land Use) wraz z projektem standardowych modeli danych dla opracowań planistycznych. Największy problem przysparzają nieostre definicje, w tym brak zdefiniowania planowania przestrzennego i dokumentu planistycznego oraz brak odpowiedniego zapisu, że opracowania planistyczne powinny być tworzone w formie baz danych z wykorzystaniem danych ewidencyjnych w postaci numerycznej.

\footnotetext{
${ }^{14}$ EGIB - Ewidencja gruntów i budynków prowadzona przez starostów.

${ }^{15}$ Art. 16 ust. 1 brzmi następująco: „Plan miejscowy sporządza się w skali 1:1000, z wykorzystaniem urzędowych kopii map zasadniczych albo w przypadku ich braku map katastralnych, gromadzonych w państwowym zasobie geodezyjnym i kartograficznym. W szczególnie uzasadnionych przypadkach dopuszcza się stosowanie map w skali 1:500 lub 1:2000, a w przypadkach planów miejscowych, które sporządza się wyłącznie w celu przeznaczenia gruntów do zalesienia lub wprowadzenia zakazu zabudowy, dopuszcza się stosowanie map w skali 1:5000".
} 
Istnieje potrzeba zaktualizowania przepisu art. 16 ustawy z dnia 27 marca 2003 roku o planowaniu i zagospodarowaniu przestrzennym, w którym należy wskazać właściwe dane ewidencyjne, jakie mają być wykorzystywane do tworzenia opracowań planistycznych na poziomie lokalnym. Warto rozważyć ustanowienie, na określonych warunkach, nowego miejscowego planu ogólnego dla obszaru całej gminy, w zależności od potrzeb, w skali 1:5000, 1:10 000, 1:20 000 .

Szczególnym wyzwaniem dla metodyki planowania zintegrowanego jest uwzględnienie czynnika czasu. Strategiczne planowanie powinno obejmować dłuższe okresy, np. 30 lat. W warunkach gospodarki rynkowej i globalizacji nie ma możliwości przewidzenia kierunków i skali tych zmian. Odpowiedzią na to może być wyłącznie planowanie kroczące. Konieczna jest wieloletnia prognoza finansowa i wieloletni plan inwestycyjny. Rekomenduje się dobre praktyki, jakie były wykorzystane przy tworzeniu Koncepcji kierunków rozwoju przestrzennego metropolii Poznań.

W Polsce obserwuje się brak kompleksowego podejścia do konstruowania od podstaw krajowej infrastruktury danych przestrzennych z uwzględnieniem potrzeb użytkowników.

Powinny być rozstrzygnięte kwestie ewentualnego udostępniania map lokalizacji decyzji lub utworzenia nowego typu dokumentu planistycznego o charakterze regulacyjno-operacyjnym. Autorzy artykułu zwracają uwagę na niewykorzystany potencjał krajowej infrastruktury informacji przestrzennej, która miała w założeniu wspierać planowanie społeczno-gospodarcze i przestrzenne (poprzez zasilanie infrastruktury zbiorami danych przestrzennych i powtórne ich wykorzystanie z użyciem usług sieciowych). W odniesieniu do monitorowania zmian w zagospodarowaniu przestrzennym warto rozważyć zdefiniowanie i monitorowanie porównywalnych stref polityki przestrzennej, ustanowionych dla obszaru gminy, spójnych ze specyfikacją INSPIRE, i wykorzystać w tym celu rekomendacje zawarte w eksperckich opracowaniach. Potrzebne są wytyczne dotyczące zakresu i sposobu opracowywania planu zagospodarowania województwa.

Ponadto wyniki badań wykazują możliwości technologiczne i organizacyjne udostępniania dodatkowych, nowych zbiorów danych przestrzennych pod warunkiem dostosowania ich do wymagań regionalnych węzłów IIP (opisane zbiory danych z georeferencją) oraz wprowadzenia odpowiednich mechanizmów prawnych. Przy czym odnośnie do regionalnych węzłów IIP, należy udostępniać te zbiory danych, za które odpowiada marszałek, natomiast zbiory z poziomu lokalnego (powiat/gmina) należy integrować poprzez usługi sieciowe (np. WMS czy WFS) bezpośrednio z ich źródła.

Jako priorytet rekomenduje się badania, działania, których celem będzie wsparcie kształtowania się nowego dialogu terytorialnego na obszarach tworzących się metropolii, nowych metod zarządzania regionem z wykorzystaniem metod foresight, poprzez stworzenie możliwości dostarczania jak najbardziej aktualnych, kompletnych informacji o sytuacji społeczno-gospodarczej i przestrzennej regionu. Planowana jest druga część badania ankietowego skierowanego do urzędów marszałkowskich.

\section{Literatura \\ References}

Anusz, S. (2008). Opis dokonań planowania przestrzennego na podstawie kolejnych edycji monitoringu. W: W. Siemiński (red.). Planowanie przestrzenne w Polsce po wprowadzeniu 
ustroju samorządowego - diagnoza stanu, nowe propozycje. Warszawa: Instytut Gospodarki Przestrzennej i Mieszkalnictwa, 89-156.

Bereskova, K., Nijkamp, P. (2018). Smart cities: A challenge to research and policy analysis, Cities. Pozyskano z http://dx.doi.org/10.1016/j.cities

Budowa infrastruktury informacji przestrzennej $w$ Ministerstwie Infrastruktury i Rozwoju w etapie obejmującym lata 2014-2015 (2018, 24 maja). Rada Infrastruktury Informacji Przestrzennej. Pozyskano z http://www.radaiip.gov.pl/_data/assets/pdf_file/0008/29564/ Zal6_A_Program_Budowy_IIP_MIiR_zp.pdf

Budowa infrastruktury informacji przestrzennej $w$ Ministerstwie Transportu, Budownictwa i Gospodarki Morskiej w etapie obejmującym lata 2013-2014 (2018, 24 maja). Rada Infrastruktury Informacji Przestrzennej. Pozyskano z http://www.radaiip.gov.pl/_data/ assets/pdf_file/0003/29586/MTBiGM_zp.pdf

Chmielewski, J.M. (2008) Analiza zmian legislacyjnych dokonywanych od 1961 do 2003 roku, z punktu widzenia charakterystyki zmian ustrojowych i ich wpływ na usytuowanie (kompetencje, prawa i obowiązki) wszystkich podmiotów biorących aktywny udział w planowaniu i rzutujących na sprawność procesu planowania. W: W. Siemiński (red.). Planowanie przestrzenne w Polsce po wprowadzeniu ustroju samorzq̨du. Diagnoza stanu i nowe propozycje. Warszawa: Instytut Gospodarki Przestrzennej i Mieszkalnictwa, 7-88.

Ciołkosz, A., Bielecka, E., Kozubek, E., Anusz, S. (2008). Monitoring zagospodarowania przestrzennego. W: K. Saganowski, M. Zagrzejewska-Fiedorowicz, P. Żuber (red.). Ekspertyzy do Koncepcji przestrzennego zagospodarowania kraju 2008-2033, IV, 678-699.

Dyrektywa 2007/2/WE Parlamentu Europejskiego i Rady z 14 marca 2007 r. (INSPIRE) ustanawiająca infrastrukturę informacji przestrzennej we Wspólnocie Europejskiej.

D2.8.III.4 Data Specification on Land Use - Draft Guidelines (2015, 12 listopada). Pozyskano z http://inspire.ec.europa.eu/documents/Data_Specifications/INSPIRE_DataSpecification_ LU_v3.0.pdf

Gutry-Korycka, M. (red.) (2005). Urban sprawl. Warsaw agglomeration, case study. Warsaw: Warsaw University Press.

Hołuj, A., Lityński, P. (2016). Następstwa ekonomiczne efektu urban sprawl. W: A. Noworól, A. Hołuj (red.). Społeczno-ekonomiczne przemiany w strefie podmiejskiej miast: studium przypadku Krakowskiego Obszaru Metropolitalnego. Warszawa: CeDeWu, 133-146.

Izdebski, W. (2018). Dobre praktyki udziału gmin i powiatów w tworzeniu infrastruktury danych przestrzennych $w$ Polsce. Warszawa: Geo-System Sp. z o.o.

Jewtuchowicz, A. (2014). Terytorium i problemy sterowania jego rozwojem. W: Regionalna polityka wspierania konkurencyjności i innowacyjności przedsiębiorstw. Studium porównawcze regionu łódzkiego i regionu Umbrii. Łódź: Wydawnictwo Uniwersytetu Łódzkiego i Regionu Umbrii, 27.

Kistowski, M. (2007). Kolizje i konflikty środowiskowe w planowaniu przestrzennym na obszarach cennych przyrodniczo. Czasopismo Techniczne, 7A, 249-255.

Koncepcja kierunków rozwoju przestrzennego metropolii Poznań - projekt (2015, luty). Poznań: Centrum Badań Metropolitalnych Uniwersytetu im. Adama Mickiewicza. Pozyskano z http://planowanie.metropoliapoznan.home.pl/planowanie/dokumenty/

Kowalewski, A., Mordasewicz, J., Osiatyński, J., Regulski, J., Stępień, J., Śleszyński, P. (2014). Ekonomiczne straty i społeczne koszty niekontrolowanej urbanizacji w Polsce - wybrane fragmenty raportu. Samorząd Terytorialny, 4(280), 5-21.

Kozłowski, S. (red.) (2006). Żywiołowe rozprzestrzenianie się miast. Narastający problem aglomeracji miejskich w Polsce. Lublin: Katedra Ochrony Środowiska Katolickiego Uniwersytetu Lubelskiego, Komitet „Człowiek i Środowisko” Polskiej Akademii Nauk.

Lackowska, M. (2009). Zarządzanie obszarami metropolitalnymi w Polsce - między dobrowolnościq a imperatywem. Warszawa: Wydawnictwa Uniwersytetu Warszawskiego.

Malczewski, P. (2015, 12 listopada). Autorska ocena projektu standardowych modeli danych oraz profilu metadanych dla opracowań planistycznych oraz „profilu metadanych Plan4All” wraz z autorską analizą w zakresie branżowego profilu metadanych w zagospodarowaniu przestrzennym pod kątem różnic i skutków dla tworzonej infrastruktury informacji przestrzennej wynikające z doświadczeń projektowych - seminarium, 1-2 grudnia 2011 r. Pozyskano z https://www.igpim.pl/wp-content/ uploads/2013/01/Profil_metadanych_PM.pdf 
Michalak, J. (2011). Opinia przywołana przez J. Przywara. Geodeta, 11.

Mikuła, Ł., Kaczmarek, T., Gadziński, J., Bul, R. (red.) (2016). Integracja planowania przestrzennego w metropolii Poznań - problemy, metody, osiagnięcia. Poznań: Biblioteka Aglomeracji Poznańskiej, 27.

Nowakowska, A., Szlachta, J. (red.) (2017). Terytorialny wymiar polityki regionalnej. Polskie doświadczenia. Warszawa: Biuletyn Komitetu Przestrzennego Zagospodarowania Kraju Polskiej Akademii Nauk, 268.

Parzyński, Z. (2011). Prezentacja w ramach przedmiotu normy geograficzne. Wydział Geodezji i Kartografii, Politechnika Warszawska, rok akademicki 2010/2011.

Rada Infrastruktury Informacji Przestrzennej (2017, 11 września). Pozyskano z http://www.radaiip.gov.pl/rada/posiedzenia/posiedzenie-w-dniu-11-wrzesnia-2017

Rozporządzenie z dnia 23 listopada 2010 r. Komisji (UE) nr 1089/2010 w sprawie wykonania dyrektywy 2007/2/WE Parlamentu Europejskiego i Rady w zakresie interoperacyjności zbiorów i usług danych przestrzennych.

Salais, R., Storper, M. (1993). Les mondes de production., Paris: L Ecole des Hautes Etudes en Sciences Sociales.

Schrank, M., Neuschmid, J., Petti, D., Wasserburger, W. (2011, 12 listopada) Interoperability, SDI and spatial planning. Plan4all Project Interoperability for Spatial Planning. Plan4all Consortium. Pozyskano z www.plan4all.eu/extractor/fileReader.php?file=plan4all-book-web.pdfwww.plan4all.eu/extractor/fileReader.php?file=plan4all-book-web.pdf

Sikora-Fernandez, D. (2018). Smarter cities in a post-socialist country: Example of Poland. Cities, 78. http://dx.doi.org/10.1016/j.cities.

Słupińska, M. (2014). Regionalna polityka wspierania konkurencyjności i innowacyjności przedsiębiorstw. Studium porównawcze regionu łódzkiego i regionu Umbrii. Łódź: Wydawnictwo Uniwersytetu Łódzkiego i Regionu Umbrii, 7-11.

Stelmach-Fita, B. (2011). Udostępnienie treści planistycznych w celu zintegrowanego zarządzania przestrzenią miejską. W: K. Gruszecka-Guranowska K. (red.). Miasto zwarte. Miasto rozproszone. Materiały ogólnopolskiej konferencji doktorantów Wydziału Architektury Politechniki Warszawskiej, Warszawa, 4-5.11.2011. Warszawa: Wydział Architektury Politechniki Warszawskiej, 45-57.

Stelmach-Fita, B. (2014). Publiczny dostęp do danych o zagospodarowaniu przestrzennym: potrzeby i ograniczenia. W: Współczesne uwarunkowania gospodarowania przestrzeniq - szanse i zagrożenia dla zrównoważonego rozwoju. Seria „Monografie. Gospodarka Przestrzenna”. Warszawa: Wydział Geodezji Politechniki Warszawskiej.

Stelmach-Fita, B. (2016). Rola geoinformacji we współdziałaniu jednostek samorządu terytorialnego z przedsiębiorcami. Przedsiębiorczość-Edukacja, 12.

Stelmach-Fita, B. (2017). Europejskie źródła danych w zakresie zagospodarowania przestrzennego: potrzeby i ograniczenia. Prace Komisji Geografii Przemysłu Polskiego Towarzystwa Geograficznego, 31(3).

Stelmach-Fita, B., Bartoszczuk, P., Pękalska, M. (2017). Monitorowanie oraz udostępnianie informacji o zjawiskach społeczno-gospodarczych i przestrzennych w Polsce. Prace Komisji Geografii Przemysłu Polskiego Towarzystwa Geograficznego, 31(3).

Stelmach-Fita, B., Brodowicz, D. (2017). Baza wiedzy o regionie i jej rola w rozwoju terytorium. Biuletyn Komitetu Przestrzennego Zagospodarowania Kraju Polskiej Akademii Nauk, 268, 186-208.

STRATEG GUS (2018, 10 czerwca). Pozyskano z http://strateg.stat.gov.pl/

Śleszyński, P. (2013). Propozycja kompleksowej koncepcji wskaźników zagospodarowania i ładu przestrzennego. Biuletyn Komitetu Przestrzennego Zagospodarowania Kraju Polskiej Akademii Nauk, 252, 176-231.

Śleszyński, P. (2015). Błędy polskiej polityki przestrzennej i krajobrazowej oraz propozycje ich naprawy. Problemy Ekologii Krajobrazu, 40, 27-44.

Śleszyński, P., Bański, J., Degórski, M., Komornicki, T., Więckowski, M. (2007). Stan zaawansowania planowania przestrzennego w gminach. Prace Geograficzne, 211.

Śleszyński, P., Deręgowska, A., Mazurek, D., Stępniak, M., Sudra, P., Zielińska, B. (2017). Analiza stanu i uwarunkowań prac planistycznych w gminach w 2015 roku. Warszawa: Instytut 
Geografii i Przestrzennego Zagospodarowania PAN na zlecenie Ministerstwa Infrastruktury i Budownictwa, maszynopis.

Śleszyński, P., Izdebski, W., Malinowski, Z., Kursa, M. (2018). Analiza morfometryczna planów miejscowych w Polsce. W: Commission of Technical Rural Infrastructure. Cracow: Polish Academy of Sciences. Cracow Branch, II(1), 331-347.

Śleszyński, P., Komornicki, T., Solon, J., Więckowski, M. (2012). Planowanie przestrzenne w gminach. Warszawa: Wydawnictwo Akademickie Sedno, Instytut Gospodarki i Zagospodarowania Przestrzennego Polskiej Akademii Nauk.

Śliwiński, A. (2008). Badanie stanu rozwoju metod i technik informatyzacji planowania przestrzennego w Polsce na tle doświadczeń niemieckich oraz propozycje wprowadzenia rozwiązań standardowych w cały proces planowania przestrzennego z wdrożeniem otwartego systemu udostępniania informacji o planach. W: W. Siemiński (red.). Planowanie przestrzenne w Polsce po wprowadzeniu ustroju samorzqdowego - diagnoza stanu, nowe propozycje. Warszawa: Instytut Gospodarki Przestrzennej i Mieszkalnictwa, 291-320.

Topczewska, T. (2010). Zintegrowane planowanie rozwoju i rewitalizacji miast w wybranych krajach „starej” UE i w Polsce. Człowiek i Środowisko, 34(1-2), 5-25.

Uchwała Rady Ministrów nr 14/2016 z dnia 16 lutego 2016 r. w sprawie przyjęcia „Planu na rzecz odpowiedzialnego rozwoju".

Urban Atlas. (2018, 24 maja). European Environment Agency. Pozyskano z http://www.eea.europa.eu/data-and-maps/figures/urban-atlas

Ustawa z dnia 4 marca 2010 roku o infrastrukturze i informacji przestrzennej (Dz.U. z 2010 r. nr 76, poz. 489, z późn. zm.).

Wdowicka, M., Mierzejewska, L. (2012). Chaos w zagospodarowaniu przestrzennym stref podmiejskich jako efekt braku zintegrowanego systemu planowania (na przykładzie strefy podmiejskiej Poznania). Problemy Rozwoju Miast, 1, 40-52.

Źróbek-Różańska, A., Zysk, E. (2015). Real estate as a subject of spatial conflict among central and local authorities. Real Estate Management and Valuation, 23(2), 88-98. DOI: 10.1515/ remav-2015-0018

Beata Stelmach-Fita, dr inż. architekt, adiunkt, Uniwersytet Pedagogiczny w Krakowie, Instytut Geografii, Zakład Przedsiębiorczości i Gospodarki Przestrzennej. Absolwentka Wydziału Architektury Politechniki Warszawskiej, doktor nauk technicznych w dyscyplinie architektura i urbanistyka, specjalizacja planowanie przestrzenne. Jej zainteresowania badawcze dotyczą porządkowania geoinformacji w Polsce na temat zagospodarowania przestrzennego oraz upowszechniania technologii GIS dla potrzeb zarządzania przestrzenią miejską. Jest autorką projektów budynków użyteczności publicznej, mieszkalnych, miejscowych planów zagospodarowania przestrzennego. Posiada doświadczenie w pracy $\mathrm{w}$ jednostkach samorządu terytorialnego (w tym wdrażanie GIS dla potrzeb Urzędu M. St. Warszawy) oraz w administracji centralnej. Otrzymała rekomendacje Izby Architektów RP do prac w komisjach dotyczących tematu danych przestrzennych dot. zagospodarowania przestrzennego (w 2014 roku). Rada Wydziału Architektury Politechniki Warszawskiej przyznała jej w 2013 roku wyróżnienie za rozprawę doktorską.

Beata Stelmach-Fita, Ph.D., Pedagogical University of Cracow, Institute of Geography, Department of Entrepreneurship and Spatial Management. Architecture graduate from Warsaw University of Technology, doctor of technical sciences in Architecture and Urbanism, specialising in spatial planning. Her research interests relate to organising geoinformation in Poland on the topic Land Use and dissemination of GIS technology for urban management. She is the author of projects of public and residential buildings, local spatial development plans. She has experience in local and central government. The Council of Architecture Faculty of the Warsaw University of Technology awarded her the honor for her doctoral dissertation. In 2014 she received the recommendations of the Chamber of Architects for work in the committees on spatial data theme of Land Use.

\section{Adres/address:}

Uniwersytet Pedagogiczny

Instytut Geografii

Zakład Przedsiębiorczości i Gospodarki Przestrzennej

ul. Podchorążych 2, 30-084 Kraków, Polska

e-mail: bfita@up.krakow.pl 
Monika Pękalska, dr inż. architekt, adiunkt, Uniwersytet Warszawski, Wydział Geografii i Studiów Regionalnych, Instytut Studiów Regionalnych i Globalnych, Zakład Geografii Rozwoju i Planowania Przestrzennego. Absolwentka Politechniki Warszawskiej, na kierunku architektura, doktor nauk technicznych w dyscyplinie architektura i urbanistyka, specjalizacja planowanie przestrzenne. Przez szereg lat pracownik pracowni urbanistycznych, w tym M. St. Warszawy. Brała udział w sporządzaniu różnego typu analiz i studiów urbanistycznych oraz miejscowych planów zagospodarowania przestrzennego dla Warszawy i terenów podmiejskich. Uczestniczka stypendiów (École d'Architecture de Paris-La Villette, Institut für Stadt- und Regionalplanung TUB Fakultat VI), grantów, konferencji i warsztatów urbanistycznych. Jej zainteresowania badawcze koncentrują się wokół zagadnień związanych z planowaniem przestrzennym w skali lokalnej, projektowaniem urbanistycznym, rewitalizacją oraz wykorzystaniem technologii GIS w planowaniu przestrzennym.

Monika Pękalska, Ph.D., University of Warsaw, Faculty of Geography and Regional Studies. Architecture graduate from Warsaw University of Technology, doctor of technical sciences in Architecture and Urbanism, specializing in spatial planning. She is experienced in urban planning, including working in Warsaw. She has participated in preparing various types of analyses, urban studies, and spatial development plans for Warsaw and its suburbs. She has received many scholarships (Ecole d'Architecture de Paris La Villette, Institut fur Stadt- und Regionalplanung TUB Fakultät VI), grants, has taken part in conferences and workshops in urban planning. Her research interests focus on issues related to spatial planning at the local level, urban design, revitalisation and the use of GIS technology in spatial planning.

\title{
Adres/address:
}

\author{
Uniwersytet Warszawski \\ Wydział Geografii i Studiów Regionalnych \\ Instytut Studiów Regionalnych i Globalnych \\ Zakład Geografii Rozwoju i Planowania Przestrzennego \\ ul. Krakowskie Przedmieście 30, 00-927 Warszawa, Polska \\ e-mail: m.pekalska@uw.edu.pl
}

Paweł Bartoszczuk, dr inż., Szkoła Główna Handlowa, Instytut Przedsiębiorstwa. Absolwent Politechniki Warszawskiej, na kierunku biotechnologia w ochronie środowiska, dr nauk ekonomicznych, pracownik naukowy Instytutu Przedsiębiorstwa Szkoły Głównej Handlowej. Stypendysta rządu Japonii - Japan Society for Promotion of Science. Wykładowca i stażysta na Northeastern Illinois University w Chicago oraz Aarhus Univeristy w Danii. Ekspert grup roboczych i zadaniowych Eurostatu i Parlamentu Europejskiego. Kierownik projektów badawczych finansowanych przez Komitet Badań Naukowych oraz Narodowe Centrum Nauki. Członek komitetów organizacyjnych i naukowych międzynarodowych konferencji Enviroinfo, Water Economics and Statistics, Risk analysis, międzynarodowych warsztatów dotyczących modelowania statystycznego i symulacji w naukach, medycznych, ekonomicznych i społecznych w Chicago. Autor ponad 90 publikacji naukowych krajowych i zagranicznych Posiada wieloletnie doświadczenie w zakresie projektów międzynarodowych dotyczących wdrażania ramowej dyrektywy wodnej. Autor ekspertyz dla Komisji Europejskiej z zakresu środowiska i gospodarki wodnej oraz Banku Światowego.

Paweł Bartoszczuk, Ph.D., Warsaw School of Economics, Institute of Business. Graduate of Warsaw University of Technology, Biotechnology, PhD in Economics, researcher at the Warsaw School of Economics. He has received a scholarship from Japan Society for Promotion of Science. Lecturer and intern at the Northeastern Illinois University in Chicago, and the University of Aarhus in Denmark. Expert at Eurostat and the European Parliament. Head of research projects funded by the National Science Centre. Member of the organising committee and international scientific conferences Enviroinfo, Water Economics and Statistics, Risk analysis, international workshops on statistical modelling and simulation sciences, medical, economic and social conditions in Chicago. Author of over 90 publications, expertises for the European Commission in the field of environment and Water and the World Bank. Expert in international projects related to the implementation of the Water Framework Directive.

\section{Adres/address:}

Szkoła Główna Handlowa,

Instytut Przedsiębiorczości

al. Niepodległości 162, 02-554 Warszawa, Polska

e-mail: pbarto1@sgh.waw.pl 